\title{
Influence of foliar nutrients on phenol levels in leaves of Eugenia uniflora
}

\author{
Rosa M. Santos, ${ }^{1}$ Gilmara A. C. Fortes, ${ }^{1}$ Pedro H. Ferri, ${ }^{2}$ Suzana \\ C. Santos ${ }^{*, 2}$
}

Revista Brasileira de Farmacognosia

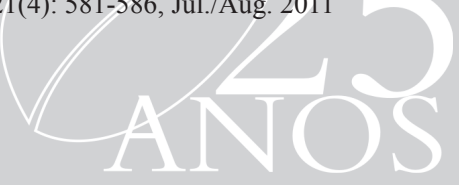

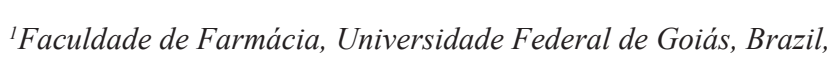 \\ ${ }^{2}$ Instituto de Química, Universidade Federal de Goiás, Brazil.
} Abstract: Eugenia uniflora L., Myrtacea, leaves contain high amounts of phenolic

Abstract: Eugenia uniflora L., Myrtaceae, leaves contain high amounts of phenolic compounds which are responsible for several pharmacological activities. In order to evaluate the phenolics seasonal variation leaves were analysed on a monthly basis during the period of two years for the contents of hydrolysable tannins, total phenols, flavonoids, and nutrients ( $, \mathrm{P}, \mathrm{K}, \mathrm{S}, \mathrm{Ca}, \mathrm{Mg}, \mathrm{Mn}, \mathrm{Zn}, \mathrm{Cu}$, and $\mathrm{Fe}$ ). Results were correlated with climate conditions (rainfall, humidity, and mean temperature) by Principal Component and Cluster Analysis which allowed four groups to be distinguished with respect to the age of the leaves and the content of some metals. Young leaves were characterised by high levels of $\mathrm{Zn}$ and nitrogen whereas old leaves contained high levels of $\mathrm{Fe}$ and calcium, and both groups had moderate amounts of phenolics. Adult leaves were divided in two groups and results revealed that while one group had the highest levels of all phenols and lowest amounts of $\mathrm{Mn}$ and $\mathrm{Cu}$, the other showed opposite quantities. The Canonical Correlation Analysis confirmed a highly significant negative correlation between phenol contents and $\mathrm{Mn}$ and $\mathrm{Cu}$. These facts suggested that flavonoids and tannins production depends of the amounts of foliar nutrients, $\mathrm{Cu}$ and $\mathrm{Mn}$ in particular, which are cofactors of enzymes involved in phenol degradation and lignin biosynthesis. This knowledge can improve this specie cultivation in order to enhance the phenolic compounds concentration.

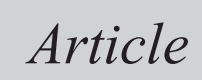

Received 20 Oct 2010

Accepted 25 Nov 2010 Available online 24 Jun 2011

Keywords:

ellagitannins

Eugenia uniflora

flavonoids

foliar mineral nutrientes pitangueira

ISSN $0102-695 \mathrm{X}$ doi: 10.1590/S0102-695X2011005000089

\section{Introduction}

Eugenia uniflora L., Myrtaceae, also known as "pitangueira", is a semi-deciduous tree which is widespread in Brazil and in other countries of South America. Its leaves have been used in folk medicine for the treatment of diarrhea (Brandelli et al, 2009), inflammation (Schapoval et al., 1994), hyperglycemia, hyperlipidemia, hypertriglycemia (Arai et al., 1999; Matsumura et al., 2000) and hypertension (Consolini et al., 1999). In addition, they have been used as an antimalarial and spasmolytic agent (Wazlawik et al., 1997; Morioka et al., 2000) as well as an inhibitor of DNA polymerase, maltase, sucrase, and $\alpha$-glucosidase (Lee et al., 2000; Matsumura et al., 2000).

The leaves of this plant are rich in polyphenol compounds, such as tannins and flavonols (Auricchio et al., 2007). Phytochemical studies have isolated three macrocyclic ellagitannin dimmers: oenothein B, eugeniflorins $\mathrm{D}_{1}$ and $\mathrm{D}_{2}$, and the flavonol myricitrin (Lee et al., 1997). Previous studies have identified oenothein $\mathrm{B}$ as responsible for the inhibition of 60 kDa heat-shock protein (HSP60) and $(1,3)$ - $\beta$-glucan synthase (Pbfks1) transcript of Paracoccidioides brasiliensis (Santos et al., 2007), the etiological agent of one of the most prevalent human systemic mycosis in Latin America.

Tannin and terpenoid amounts alter during the development of the plant and also as a response to environmental changes (Salminen et al., 2001; Salminen et al., 2004; Scogings et al., 2004; Santos et al., 2006; Solar et al., 2006; Fang et al., 2011). Previous studies showed the seasonal influence on the terpenoids composition of the E. uniflora leaves oil (Costa et al., 2009). These variations influence directly the quality of the leaves as a medicinal plant.

The aim of this study was to investigate the influence of seasonal variations of foliar macro and micronutrients, climate factors such as temperature, rainfall, and humidity on the levels of tannins and flavonoids in E. uniflora leaves. The results obtained will possibly contribute to an understanding of the phenolic metabolism in this plant, as well as the cultivation conditions to reach higher amounts of pharmacological active compounds.

\section{Materials and Methods}

Plant material and climatic data 
Eugenia uniflora L., Myrtaceae, adult green leaves were collected monthly in the city of Anápolis (16²0'12.8”S, 48 56'19.3”W), Goiás State, Brazil, during the period between Dec/2001 and Dec/2003. Samples were authenticated by Professor Heleno D. Ferreira at Departamento de Biologia Geral, Universidade Federal de Goiás. Voucher specimens are deposited at the Herbarium of Universidade Federal de Goiás (UFG, code number 25477). The Air Base of Anápolis-Goiás provided climate data of the study period.

\section{Sample preparation}

Dried and grounded leaves $(10 \mathrm{~g})$ were extracted with acetone:water 7:3 (4 x $50 \mathrm{~mL})$ by stirring in an erlenmeyer at room temperature. Each extract was evaporated under vacuum to $30 \%$ volume, filtered in order to remove fats and chlorophylls, and then freezedried.

\section{Colorimetric assays}

The total phenolic contents of the extracts were determined using $\mathrm{FeCl}_{3}$ following the adaptation (Mole \& Waterman, 1987) of the Hagerman and Butler method (1978). Hydrolysable tannins were quantified using $\mathrm{KIO}_{3}$ (Willis \& Allen, 1998) and were also measured by the protein precipitation assay with the use of Bovine Serum Albumine (Hagerman \& Butler, 1978). The total flavonoid content was determined by a modification of the Pharmacopoeia Helvetica method (Petry et al., 1998) using $\mathrm{AlCl}_{3}$. All samples in the four assays were analysed in triplicates and the standard curves were constructed with tannic acid (Merck) for total phenolics, hydrolysable tannins, and protein precipitation assays. Rutin was used to prepare the standard curve for total flavonoid assay.

\section{Foliar nutrient analysis}

Samples were digested with nitric-perchloric acid. Concentrations of $\mathrm{K}, \mathrm{Ca}, \mathrm{Mg}, \mathrm{Cu}, \mathrm{Fe}, \mathrm{Mn}$, and $\mathrm{Zn}$ were measured by flame atomic absorption spectrometry (AAS, Perkin Elmer), phosphorous and sulphur were determined by spectrophotometry, and $\mathrm{N}$ content was assessed by the standard Kjeldahl procedure. Three replicate measurements were performed per plant sample.

\section{Statistical analyses}

Principal component analysis (PCA) and Cluster analysis (CA), with the use of SPAD.N software package (Lebart et al., 1994), were applied to examine the interrelationships between the climatic data, foliar nutrients, and the polyphenol content. Nearest neighbour complete linkage technique by Benzécri algorithm (Benzécri, 1980) was used as an index of similarity. Hierarchical clustering was performed according to Ward's variance minimizing method (Ward, 1963). Polyphenol levels and foliar nutrient relationships were obtained by a canonical correlation analysis implemented using the SAS CANCORR procedure. Average multiple comparisons were established by the Tukey test. $p$-values less than 0.05 were considered to be significant.

\section{Results and Discussion}

E. uniflora has a typical phenology in the Brazilian Cerrado which is characterised by a short period of flowering in the beginning of the rainy season and fructification occurring from October to December in the wet season. During the dry season part of the leaves falls, mainly in August and September, when the mean temperature is higher and humidity is lower. With the beginning of the rainy season there is a flush of new leaves; which grow rapidly to the maximum size.

A combination of CA and PCA showed the existence of four principal clusters which are mainly characterized by the development stage of the leaves and the foliar nutrients. The majority of the data could be represented in two main axes which contained $51.83 \%$ of total variance $(x=31.38$ and $y=20.45$; Figure 1). The First Principal Component separates samples with high contents of all phenolics from samples with lower amounts of these constituents. The strong negative correlation between phenolic variables and the variables of metals $\mathrm{Mn}$ and $\mathrm{Cu}$ is clear. The Second Principal Component showed a gradient of leave age, from young leaves (Sep-Nov, cluster I) through adult (Dec-Apr, clusters II and III) up to old leaves (MayAug, cluster IV), and distinguished samples from the rainy and dry seasons.

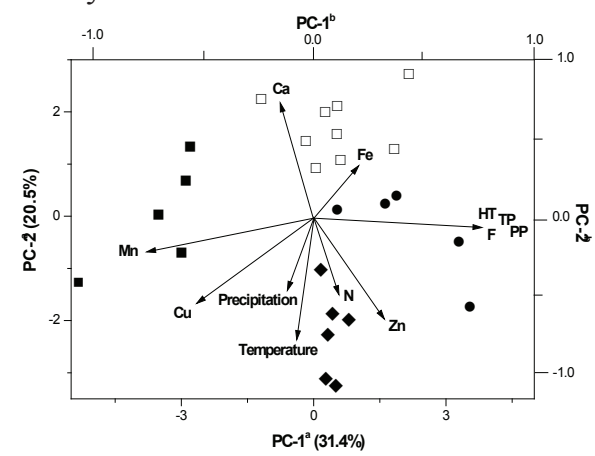

Figure 1. Scatterplot of Eugenia uniflora samples for the two principal components extracted in PCA to which cluster it

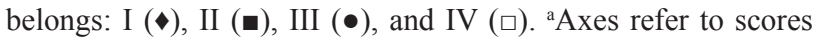
from the samples. ${ }^{\mathrm{b}}$ Axes refer to scores from the discriminants which are represented as vectors from the origin. 
Cluster I (Figure 1 and Table 1) was characterised by high levels of zinc $(19.21 \pm 1.23 \mathrm{mg} / \mathrm{kg})$, nitrogen $(3.75 \pm 1.36 \mathrm{dag} / \mathrm{kg})$, and medium temperature $\left(22.95 \pm 1.07^{\circ} \mathrm{C}\right)$, which were higher during the periods from Sep $2^{\text {nd }}$ to Nov $2^{\text {nd }}$ and from Oct $3^{\text {rd }}$ to Dec $3^{\text {rd }}$. Levels of all phenols were moderate in these periods, which correspond to the beginning of the rainy season and to an intense metabolism due to the flush of new leaves, flowering, and fruiting.

Table 1. Contents of phenolics and foliar nutrients in Eugenia uniflora leaves and climatic conditions as mean values obtained for each cluster.

\begin{tabular}{|c|c|c|c|c|}
\hline \multirow[t]{2}{*}{ Variable } & \multicolumn{4}{|c|}{ Clusters } \\
\hline & $\mathrm{I}(n=6)$ & II $(n=5)$ & III $(n=5)$ & $\mathrm{IV}(n=9)$ \\
\hline $\begin{array}{l}\text { Total phenols (TP) } \\
\left(\mathrm{mg} \mathrm{g}^{-1} \mathrm{dw}\right)\end{array}$ & $82.61 \mathrm{a}$ & $57.15 \mathrm{~b}$ & $97.86 \mathrm{c}$ & $83.68 \mathrm{a}$ \\
\hline $\begin{array}{l}\text { Astringency (PP) } \\
\left(\mathrm{mg} \mathrm{g}^{-1} \mathrm{dw}\right)\end{array}$ & $35.06 \mathrm{a}$ & $24.55 \mathrm{~b}$ & $44.55 \mathrm{c}$ & $33.43 \mathrm{a}$ \\
\hline $\begin{array}{l}\text { Hydrolysable tannins } \\
\text { (HT) }\left(\mathrm{mg} \mathrm{g}^{-1} \mathrm{dw}\right)\end{array}$ & $112.21 \mathrm{a}$ & $85.12 \mathrm{~b}$ & $134.97 \mathrm{c}$ & $118.05 \mathrm{a}$ \\
\hline $\begin{array}{l}\text { Flavonoids (FL) } \\
\left(\mathrm{mg} \mathrm{g}^{-1} \mathrm{dw}\right)\end{array}$ & $3.57 \mathrm{a}$ & $2.09 \mathrm{~b}$ & $4.23 \mathrm{a}$ & $3.36 \mathrm{a}$ \\
\hline Humidity (\%) & $69.67 \mathrm{ab}$ & $77.00 \mathrm{a}$ & $83.20 \mathrm{a}$ & $62.11 \mathrm{~b}$ \\
\hline Temperature $\left({ }^{\circ} \mathrm{C}\right)$ & $22.95 \mathrm{a}$ & $22.10 \mathrm{ab}$ & $22.04 \mathrm{ab}$ & $21.26 \mathrm{~b}$ \\
\hline Precipitation (mm) & $143.63 \mathrm{a}$ & $197.62 \mathrm{a}$ & $214.92 \mathrm{a}$ & $11.84 \mathrm{~b}$ \\
\hline $\mathrm{K}\left(\right.$ dag $\left._{\mathrm{kg}}{ }^{-1}\right)$ & $0.94 \mathrm{a}$ & $0.79 \mathrm{a}$ & $0.93 \mathrm{a}$ & $0.83 \mathrm{a}$ \\
\hline $\mathrm{Ca}\left(\operatorname{dag~kg}^{-1}\right)$ & $2.48 \mathrm{a}$ & $4.23 \mathrm{~b}$ & $4.15 \mathrm{~b}$ & $4.58 \mathrm{~b}$ \\
\hline $\mathrm{N}\left(\right.$ dag kg $\left.^{-1}\right)$ & $3.75 \mathrm{a}$ & $2.28 \mathrm{ab}$ & $2.26 \mathrm{ab}$ & $2.40 \mathrm{~b}$ \\
\hline $\mathrm{Cu}\left(\right.$ dag kg $\left.^{-1}\right)$ & $8.33 \mathrm{a}$ & $8.90 \mathrm{a}$ & $5.80 \mathrm{ab}$ & $5.33 \mathrm{~b}$ \\
\hline $\mathrm{Zn}\left(\operatorname{dag~kg}^{-1}\right)$ & $19.21 \mathrm{a}$ & $13.46 \mathrm{~b}$ & $15.33 \mathrm{bc}$ & $15.63 \mathrm{c}$ \\
\hline $\operatorname{Mn}\left(\right.$ dag kg $\left.^{-1}\right)$ & $17.58 \mathrm{ab}$ & $21.40 \mathrm{a}$ & $13.20 \mathrm{~b}$ & $15.56 \mathrm{~b}$ \\
\hline $\mathrm{Fe}\left({\left.\mathrm{dag} \mathrm{kg}^{-1}\right)}\right.$ & $350.92 \mathrm{a}$ & $251.00 \mathrm{~b}$ & $235.60 \mathrm{~b}$ & $499.11 \mathrm{a}$ \\
\hline
\end{tabular}

${ }^{a}$ Mean values followed by the same letter in row are not significantly different at 5\% level using Tukey's test.

Clusters II (Dec $1^{\text {st }}$-Apr $2^{\text {nd }}$ ) and III (Dec $2^{\text {nd }}-$ Apr $3^{\text {rd }}$ ) were both constituted by samples with adult leaves from the rainy season. However, they revealed an opposite behaviour. While cluster II presented the lowest levels of all phenols, cluster III showed the highest ones (Table 1). The difference between these groups can be correlated with concentrations of $\mathrm{Cu}$ and $\mathrm{Mn}, 8.9$ and $21.4 \mathrm{mg} / \mathrm{kg}$ in group II and 5.8 and $13.2 \mathrm{mg} / \mathrm{kg}$ in group III, respectively. In fact, the canonical correlation analysis (Table 2) shows a highly significant negative correlation between phenol contents and $\mathrm{Cu}$ and $\mathrm{Mn}$.

The last cluster (May $2^{\text {nd }}$-Aug $2^{\text {nd }}$ and May $3^{\text {rd }}$ Sep $3^{\text {rd }}$ ), which comprised samples of old leaves from the dry season, was characterised by higher levels of Fe $(499.11 \pm 158.01 \mathrm{mg} / \mathrm{kg})$ and $\mathrm{Ca}(4.58 \pm 0.83 \mathrm{dag} / \mathrm{kg})$ and moderate levels of all phenols (Table 1). In this case no significant relationships were found between the contents of $\mathrm{Fe}$ or $\mathrm{Ca}$ and tannins or flavonoids in leaves.

In contrast to previous studies (Scogings et al., 2004; Santos et al., 2006; Fang et al., 2011) the levels of all phenolics did not present any correlation with climatic changes, such as rainfall and temperature. Clusters I and IV have no significant differences in all phenol levels despite occurring in distinct seasons (Table 1). In addition, in the present study there was no direct relationship between phenols and the developmental stage of the leaves, which was an important factor for influencing phenol variation for deciduous trees from temperate climate such as Quercus robur (Salminen et al., 2004), Juglans regia (Solar et al., 2006), and Betula pubescens (Salminen et al., 2001).

Levels of phenolics in plant tissues have been related with the availability of nutrients. In the majority of studies phenolic production decreases at high nitrogen availability and increases under nitrogen deficiency (Treutter, 2010). This trend was not followed by $E$. uniflora phenolics, which showed no correlation in their contents with nitrogen levels. The same was observed for condensed tannins in Colophospermum mopane (Ferwerda et al., 2005). In fact, the canonical correlation analysis between phenols and foliar nutrients (Table 2) revealed that the first axis of phenolic constituent data (set 1) was highly correlated with the first axis of foliar nutrients (set 2 ). Indeed, the first pair of canonical variates (V1 and

Table 2. Canonical structure (loadings) of discriminant phenolic compounds and foliar nutrients with their canonical variates.

\begin{tabular}{|c|c|c|c|}
\hline Phenolic compounds (mg/g) (set 1) & Canonical variate (V1) & Foliar nutrients $(\mathrm{mg} / \mathrm{kg})($ set 2$)$ & Canonical variate (W1) \\
\hline Total phenols (TP) & 0.969 & Copper & -0.645 \\
\hline Astringency $(\mathrm{PP})$ & 0.893 & Zinc & 0.388 \\
\hline Hydrolysable tannins (HT) & 0.846 & Manganese & -0.812 \\
\hline Flavonoids (F) & 0.736 & & \\
\hline Eigenvalues & & & 1.313 \\
\hline Canonical correlation & & & 0.753 \\
\hline Wilks' Lambda & & & 0.219 \\
\hline Degrees of freedom & & & 16 \\
\hline$p$-value & & & 0.0215 \\
\hline Redundancy index (\%) & & & 42.47 \\
\hline
\end{tabular}


W1) was correlated; their canonical correlation coefficient was equal to 0.753 . Since the $p$-value of the first pair of CV was 0.022 , the considered data sets were statistically correlated ca. $98 \%$ confidence level by Wilks' multivariate lambda test and may be used to interpret the relationship between variables. Thus, phenolics revealed significant relationships with only three micronutrients $(\mathrm{Zn}, \mathrm{Cu}$, and $\mathrm{Mn}$ ) and no correlations with macronutrients.

Zinc presented a moderate positive correlation with flavonoids and hydrolysable tannin levels. Similar effects were observed for condensed tannins in seedlings of Aegiceras corniculatum (Guangqiu et al., 2007) and for flavonoids in roots of Medicago sattiva (Parry et al., 1994). However, Manthey et al. (2000) found that in citrus leaves the flavonoid concentration increased with zinc-deficiency. In fact, plants exposed to zinc had a high expression of lignin biosynthesis genes (Van de Mortel et al., 2006) which revealed the participation of this metal in the shikimic acid pathway. It is premature to affirm whether zinc influence is always positive or negative, as there are very few studies relating to phenol biosynthesis and to this metal.

On the other hand, several works have reported the involvement of $\mathrm{Cu}$ and $\mathrm{Mn}$ in the shikimic acid pathway leading to the biosynthesis of several phenols, such as flavonoids, tannins, and lignin (Santiago et al., 2000; Diaz et al., 2001; Loponen et al., 2001; Lin et al., 2005; Guangqiu et al., 2007). Moreover, it is known that $\mathrm{Cu}$ and $\mathrm{Mn}$ influence the activity of many cellular enzymes, such as phenylalanine ammonia-lyase (PAL) (Santiago et al., 2000; Kováčik \& Klejdus, 2008; Treutter, 2010), peroxidases (Diaz et al., 2001, Lin et al., 2005, Gross, 2008; Kováčik et al., 2009), laccases (Lin et al., 2005), and shikimate dehydrogenase (Diaz et al., 2001, Kováčik et al., 2009).

In plants with copper and manganese deficiency lignification is impaired and phenolics accumulate in the plant tissues (Marschner, 1997; Lin et al., 2005). Guangqiu et al. (2007) observed a dose response effect of copper on foliar condensed tannins in seedlings of Aegiceras corniculatum. At first tannins decreased with an increase in copper supply; however, when copper reached toxic levels the tannin concentration also increased. These results demonstrated that the biosynthesis of phenolic compounds is dependent on $\mathrm{Cu}$ and $\mathrm{Mn}$ levels: in deficient tissues lignification is inhibited, then so the production of other phenolics is enhanced, which is probably the case of cluster III. When $\mathrm{Cu}$ and $\mathrm{Mn}$ achieve sufficient levels (6.0 and $20 \mathrm{mg} / \mathrm{kg}$ respectively) lignin biosynthesis increases, most likely using other phenolics as intermediates.

The reduction in hydrolysable tannins in cluster II (Table 1) also could be due to the insolubilization of the ellagitannins as already observed in birch leaves. The latter showed an increase in the amount of insoluble ellagitannins related to increase in leaf toughness (Salminen et al.,
2002), indicating that part of the phenolics can be bound to cell wall polymers. In addition, the amount of polymers of ellagitannins might also be increased, as a laccase-like phenol oxidase, which is copper-dependent, is responsible for the oxidative condensation of ellagitannin monomers (Niemetz \& Gross, 2005).

In summary, the seasonal production of flavonoids and hydrolysable tannins depends of various biotic and abiotic factors and there is not a unique trend emerging from the various studies, as conflicting results have already been observed. It appears that the balance among micronutrients, such as $\mathrm{Zn}, \mathrm{Cu}$, and $\mathrm{Mn}$, may influence a competition between the different classes of phenolic compounds. In a practical view the optimization of micronutrients fertilizer levels could regulate the amounts of specific active phenolic compounds. Thus, more information concerning the possible role of these metals in the biosynthesis of each class of phenols is necessary for the improvement of medicinal plants cultivation practices.

\section{Acknowledgments}

The authors thank Dr. Denise O. Guimarães (São Paulo University) for the plant collections and CNPq and FUNAPE/UFG for financial support.

\section{References}

Arai J, Amagaya S, Komatsu Y, Okuda M, Mayashi T, Kasai M, Arisawa M, Momose Y 1999. Improving effects of the extracts from Eugenia uniflora on hyperglycemia and hypertriglyceridemia in mice. $J$ Ethnopharmacol 68 : 307-314.

Auricchio MT, Bugno A, Barros SBM, Bacchi EM 2007. Antimicrobial and antioxidant activities and toxicity of Eugenia uniflora. Lat Am J Pharm 26: 76-81.

Benzécri JP 1980. L'Analyse Des Données: La Taxinomie. vol 1. Paris: Dunod.

Brandelli CLC, Giordani RB, De Carli GA, Tasca T 2009. Indigenous traditional medicine: in vitro anti-giardial activity of plants used in the treatment of diarrhea. Parasitol Res 104: 1345-1349.

Consolini AE, Baldini OAN, Amat AG 1999. Pharmacological basis for the empirical use of Eugenia uniflora L. (Myrtaceae) as antihypertensive. J Ethnopharmacol 66: 33-39.

Costa DP, Santos SC, Seraphin JC, Ferri PH 2009. Seasonal variability of essential oils of Eugenia uniflora leaves. $J$ Braz Chem Soc 20: 1287-1293.

Diaz J, Bernal A, Pomar F, Merino F 2001. Induction of shikimate dehydrogenase and peroxidase in pepper (Capsicum annuum L.) seedlings in response to copper stress and its relation to lignification. Plant Sci 161: 179-188.

Fang S, Yang W, Chu X, Shang X, She C, Fu X 2011. Provenance and temporal variations in selected flavonoids in leaves of Cyclocarya paliurus. Food Chem 124: 1382-1386.

Ferwerda JG, Wieren SE, Skidmore AK, Prins HHT 2005. Inducing condensed tannin production in 
Colophospermum mopane: absence of response to soil N and P fertility and physical damage. Plant Soil 273: 203-209.

Gross GG 2008. From lignins to tannins: Forty years of enzyme studies on the biosynthesis of phenolic compounds. Phytochemistry 69: 3018-3031.

Guangqiu Q, Chongling Y, Haoliang L 2007. Influence of heave metals on the carbohydrate and phenolics in mangrove, Aegiceras corniculatum L., seedlings. Bull Environ Contam Toxicol 78: 440-444.

Hagerman AE, Butler LG 1978. Protein precipitation method for the quantitative determination of tannins. J Agric Food Chem 26: 809-812.

Kováčik J, Klejdus B 2008. Dynamics of phenolic acids and lignin accumulation in metal-treated Matricaria chamomilla roots. Plant Cell Rep 27: 605-615.

Kováčik J, Klejdus B, Hedbavny J, Štork F, Bačkor M 2009. Comparison of cadmium and copper effect on phenolic metabolism, mineral nutrients and stress-related parameters in Matricaria chamomilla plants. Plant Soil 320: 231-242.

Lebart L, Morineau A, Lambert T, Pleuvret P 1994. Spad.N Version 2.5. Sistema compatible para el análisis de datos. Saint Mande: Centre International de Statistique et d'Informatique Appliqueés.

Lee MH, Nishimoto S, Yang LL, Yen KY, Hatano T, Yoshida T, Okuda T 1997. Two macrocyclic hydrolysable tannin dimers from Eugenia uniflora. Phytochemistry 44: 13431349.

Lee MH, Chiou JF, Yen KY 2000. EBV DNA polymerase inhibition of tannins from Eugenia uniflora. Cancer Lett 154: 131-136.

Lin CC, Chen LM, Lui ZH 2005. Rapid effect of copper on lignin biosynthesis in soybean roats. Plant Sci 168: 855-861.

Loponen J, Lempa K, Ossipov V, Kozlov MV, Girs A, Hangasmaa K, Haukioja E, Pihlaja K 2001. Patterns in content of phenolic compounds in leaves of mountain birches along a strong pollution gradient. Chemosphere 45: 291-301.

Manthey JA, Grohmann K, Berhow MA, Tisserat B 2000. Changes in citrus leaf flavonoid concentrations resulting from blight-induced zinc-deficiency. Plant Physiol Biochem 38: 333-343.

Marschner H 1997. Mineral Nutrition of Higher Plants. 2 ed. London: Academic Press, p. 313-363.

Matsumura T, Kasai M, Hayashi T, Arisawa M, Momose Y, Arai I, Amagaya S, Omatsu Y 2000. Alpha-glucosidase inhibitors from Paraguayan natural medicine, Nangapiry, the leaves of Eugenia uniflora. Pharm Biol 38: 302-307.

Mole S, Waterman PG 1987. A critical analysis of techiniques for measuring tannins in ecological studies. Oecologia 72: 137-147.

Morioka K, Nojima H, Kurosaki F, Arisawa M, Kuraishi Y, Momose Y 2000. Hypotensive action of Nangapiry, a Paraguayan natural medicine, in rodents. Phytomedicine 7: 99-103.

Niemetz R, Gross GG 2005. Enzymology of gallotannin and ellagitannin biosynthesis. Phytochemistry 66: 20012011.

Parry AD, Tiller SA, Edwards R 1994. The effects of heavymetals and root immersion on isoflavonoid metabolism in alfalfa (Medicago sativa L.). Plant Physiol 106: 195-
202.

Petry RD, Souza KCB, Bassani VL, Petrovick PR, Ortega GG 1998. Doseamento do teor de flavonóides totais em extratos hidroalcóolicos de Passiflora alata Dryander (maracujá). Rev Bras Farm 79: 7-10.

Salminen JP, Ossipov V, Haukioja E, Pihlaja K 2001. Seasonal variation in the content of hydrolysable tannins in leaves of Betula pubescens. Phytochemistry 57: 15-22.

Salminen JP, Ossipov V, Pihlaja K 2002. Distribution of hydrolysable tannins in the foliage of finish birch species. Z Naturforsch 57c: 258-256.

Salminen JP, Roslin T, Karonen M, Sinkkonen J, Pihlaja K, Pulkkinen P 2004. Seasonal variation in the content of hydrolysable tannins, flavonoid glycosides, and proanthocyanidins in oak leaves. J Chem Ecol 30: 16931711.

Santiago LJM, Louro RP, Oliveira DE 2000. Compartimentation of phenolic compounds and phenylalanine ammonialyase in leaves of Phyllanthus tenellus Roxb. and their induction by copper sulphate. Ann Botany 86: 10231032.

Santos GD, Ferri PH, Santos SC, Bao SB, Soares CMA, Pereira M 2007. Oenothein B inhibits the expression of PbFKS1 transcript and induces morphological changes in Paracoccidioides brasiliensis. Med Mycol 45: 609-618.

Santos SC, Costa WF, Batista F, Santos LR, Ferri PH, Ferreira HD, Seraphin JC 2006. Seasonal variation in the content of tannins in barks of barbatimão species. Rev Bras Farmacogn 16: 552-556.

Schapoval EES, Silveira SM, Miranda ML, Alice CB, Henriques AT 1994. Evaluation of some pharmacological activities of Eugenia uniflora L. J Ethnopharmacol 44: 137-142.

Scogings PF, Dziba LE, Gordon IJ 2004. Leaf chemistry of woody plants in relation to season, canopy retention and goat browsing in a semiarid subtropical savanna. Austral Ecol 29: 278-286.

Solar A, Colarič M, Usenic V, Stampar F 2006. Seasonal variations of selected flavonoids, phenolics and quinones in annual shots of common walnut (Juglans regia L.). Plant Sci 170: 453-461.

Treutter D 2010. Managing phenol contents in crop plants by phytochemical farming and breeding-visions and constraints. Int J Mol Sci 11: 807-857.

Van de Mortel JE, Almar-Villanueva L, Schat H, Kwekkeboom J, Coughlan S, Moerland PD, Van Themaat EVL, Koornneef M, Aarts MGM 2006. Large expression differences in genes for iron and zinc homeostasis, stress response, and lignin biosynthesis distinguish roots of Arabidopsis thaliana and the related metal hyperaccumulator Thlaspi caerulescens. Plant Physiol 142: 1127-1147.

Wazlawik E, Silva MA, Peters RR, Correia JFG, Farias MR, Calixto JB, Ribeiro do Valle RM 1997. Analysis of the role of nitric oxide in the relaxant effect of the crude extract and fractions from Eugenia uniflora in the rat thoracic aorta. J Pharm Pharmacol 49: 433-437.

Ward JH 1963. Hierarchical grouping to optimize an objective function. J Am Statis Assoc 58: 238-244.

Willis RB, Allen PR 1998. Improved method for measuring hydrolysable tannins using potassium iodate. Analyst 123: 435-439. 
Influence of foliar nutrients on phenol levels in leaves of Eugenia uniflora Rosa M. Santos et al.

\section{*Correspondence}

\section{Suzana C. Santos}

Instituto de Química, Universidade Federal de Goiás, C.P. 131

74001-970 Goiânia-GO, Brazil

suzana@quimica.ufg.br

Tel./Fax: +55 6235211167 